\title{
Patient satisfaction with outpatient health care services: evaluation of the components of this service using regression analysis
}

\author{
Fisun Vural ${ }^{1}$, Seval Ciftci ${ }^{2}$, Yigit Cakiroglu ${ }^{3}$, Birol Vural ${ }^{3}$ \\ ${ }^{1}$ Haydarpasa Numune Training and Research Hospital, Istanbul, Turkey; \\ ${ }^{2}$ Golcuk Necati Celik Public Hospital, Kocaeli, Turkey; \\ ${ }^{3}$ Kocaeli University Faculty of Medicine, Kocaeli, Turkey;
}

\begin{abstract}
OBJECTIVE: In health care services, patient's expectations, and satisfaction levels are important markers of the services provided. The aim of this study is to determine patient satisfaction level, and its influential factors in patients receiving treatment on an ambulatory basis who applied to a state hospital.

METHODS: In this cross-sectional study a total of 210 patients were face-to-face interviewed, and patient satisfaction questionnaire survey was performed. Socioeconomic characteristics, physical conditions of the hospital, pecularities of the health care providers, and satisfaction from health care services received were questioned independently. Regression analysis was performed to investigate factors effective on patient satisfaction.

RESULTS: A significant correlation was not found between sociodemographic factors, and patient satisfaction $(p<0.05)$. Favourable patient acceptance of the health care services received is effected by the duration of the waiting period. Communication skills of the health care professionals have been found to be the fundamental factors effective on the preference or recommendation of a certain health care institute once more $(p<0.005)$.
\end{abstract}

CONCLUSION: Empowering the communication skills of health care professionals, and decreasing the waiting period were found to be necessary in order to increase the satisfaction levels of ambulatory patients

Key words: Communication; health care professional; patient satisfaction.

$\mathrm{R}$ apid developments in medicine and technology increased expectations of the individuals for medical services. The integration of technological innovations with health care services has brought with them the concept of providing health care services of good quality [1]. Fulfillment of the community's expectations and requirements, in brief, satisfaction of the receivers of the health care services is an indispensable component of institutional success. As an indicator of offering services of high quality, patient

Received: September 11, 2014 Accepted: November 12, 2014 Online: December 08, 2014

Correspondence: Dr. Fisun VURAL. Haydarpasa Numune Egitim ve Arastirma Hastanesi, Tibbiye Cad., No: 40 Uskudar, Istanbul, Turkey.

Tel: +90 216 - 5423232 e-mail: fisunvural@yahoo.com.tr

(c) Copyright 2014 by Istanbul Northern Anatolian Association of Public Hospitals - Available online at www.kuzeyklinikleri.com 
satisfaction has a significant place in the management of health care services [1]. Health care institutions are complex organizations that harbour many professional health workers from auxillary personnel to highly educated staff [2]. In this complex structure, personal characteristics of the patients, many other factors related to service providers, and institutions affect satisfaction levels of the patients [3-5]. The aim of this study is to determine satisfaction levels of the patients who applied to a state hospital to receive ambulatory health care services, and investigate relevant influential factors.

\section{MATERIALS AND METHODS}

This research is a cross-sectional and descriptive study performed between July and December 2012 in Kocaeli Gölcük Necati Çelik State Hospital. Approval for the study was obtained from the Ethics Committee of Kocaeli University. A questionnaire survey was conducted after approval received from the Chief Medical Officer. The survey includes items similar to those employed in ambulatory patient satisfaction questionnaire issued by Turkish Ministry of Health and Social Welfare (July 2011). Responses to questions were evaluated using threepoint Likert scale as "yes, no, and somewhat".

The study was performed on 210 volunteered patients who complied with the inclusion criteria, among 300 patients who applied to the Information Bureau of the Chief Medical Officer. The patients who did not complete bureaucratic procedures or applied to the outpatient clinic after working hours, and patients scheduled for operation, hospitalization or postoperative care and referred to another health care institution excluded from the study. People with examination priorities such as emergency department patients, pregnant and puerperal women, elderlies ( $>65$ years) or very young $(<16$ years) patients, psychiatric and, dialysis patients were also excluded.

The questionnaire consisted of 4 primary domains, and 20 items and a survey study realized with face-to-face interviews.

1. Descriptive characteristics of the patients asked (patient's age, gender, educational level, pro- fession, social security coverage).

2 . The section related to the health care professionals (attitudes, and behaviours of the physician, and the staff, attention to personal intimacy, sufficient time reserved for physical examination, and informing the patient).

3. Questions related to physical conditions and bureaucratic procedures of the institution (comfort of the patient registration / admission office, waiting time for one's turn for registration -examination / analysis, cleanliness of the place).

4. Thoughts about the hospital (advisability, preferring the same institution once more and quality of the health care service).

To investigate participants' preference, recommendations for health care institute, favourable acceptance of the service, factors related to institutional and health care providers were questioned separately. Institutional factors were comfortability of the waiting area of registration/admission office, general cleanliness of the outpatient clinics, shorter waiting period for one's turn for examinations/analyses. Factors related to health care providers were examining physician's sparing time for informing the patients about their disease(s), rapport between examining doctor and the staff, and respecting a patient intimacy.

\section{Statistical analysis}

For the statistical evaluation of data, we used SPSS 14.0 (Statistical Package for Social Sciences) for Windows 97 program. The $p$-value $<0.05$ was accepted as the level of statistical significance, and all analyses bidirectionally evaluated within 95\% confidence interval. In addition to descriptive statistical methods, the relationship between parametric/nonparametric variables was analyzed using Pearson/ Spearman correlation coefficients. Besides, components of the health care services were evaluated using regression analysis (use of linear or logistic regression analysis whether data were parametric or nonparametric). Internal consistency and reliability of the satisfaction questionnaire were analysed, and the result was expressed with Cronbach's alpha coefficient. Calculation of Satisfaction Coefficient 
performed in compliance with 2012 Application Guideline of Questionnaire reported by Turkish Republic Ministry of Health Directorate of Department of Performance Management and Quality Development Calculation of coefficient was based on the following formula:

Ambulatory Patient: (Total score /number of participants) x 100/ 36 .

\section{RESULTS}

Internal consistency, and reliability of the satisfaction questionnaire were analyzed, and Cronbach's alpha coefficient was found to be 0.80 . Starting from this data, we can say that our questionnaire survey is reliable. Study participants $(n=210)$ consisted of female $(48.6 \%)$, and male $(51.4 \%)$ patients. They were mostly $(77.1 \%)$ married, and $50.4 \%$ of them aged less than 35 years. Vast majority of them were housewives and workers. Nearly all of them (97.1\%) did not consult to the hospital for the first time. Satisfaction rate of the ambulatory patients estimated as 96.31 percent. Table 1 shows the sociodemographic characteristics of the patients. The correlation between sociodemographic factors, favourable acceptance of health care services, preference, and the advisability of an institution was not detected $(p>0.05)$.

I. Preference for the same institution once more: Nearly all (93.3\%) participants preferred the same organization for the second time. Factors related to the institution and health care personnel were associated with preference for the institution for the second time (Table 2). Regression analysis of these factors revealed that health care staff is as an independent and significant factor for preference of hospital [health care personnel ( $p=0.000$ CI: $0.241-0.472$ ) and physician ( $p=0.001 \mathrm{CI}:-0.33-0.08)$ ] (Table 3).

II. Recommending an individual institution: Majority of the $(92.9 \%)$ patients found the institution worthy of recommendation. Many factors related to an institution, and health care personnel were found to correlate with preference for the institution for the second time. Table 2 shows the results. The correlated factors were entered into regression analysis to find associates of advisability.

TABLE 1. Sociodemographic characteristics of the patients participating in the study

$\mathrm{n}$

Gender

Female

Male

Marital status

Married

Single

Age (years)

16-35

36-55

$56-65$

$>66$

Education

Illiterate

Literate

Primary school

Secondary school

University

Profession

Unemployed

Retired

Tradesman

Officer

Worker

Housewife

Student

Social security coverage

Yes

None
102

108

162

48

106

67

25

12

\section{2}

10

99

75

24

6

33

16

9

66

68

12

189

21
48.6

51.4

77.1

22.9

50.4

31.9

11.9

5.8

0.95

4.75

47.2

35.7

11.4

15.7

7.6

4.3

31.4

32.4

5.7

Any correlation was not detected between sociodemographic factors, global satisfaction with health care services, preferring, and recommending a medical institution ( $p>0.05)$.

Communication skills of the physician $(p=0.000$ CI: 0.14-0.43), and health care personnel $(p=0.037$ $\mathrm{CI}:-0.32-0.01)$ were the independent factors that significantly predicted advisability of institution. Table 3 presents the details of the analysis.

III. Global approval of health care services: Nearly all (94\%) patients favorably evaluated health care services provided which was found to be related to many factors. Table 2 presents the results. In regres- 
TABLE2. Factors related to recommending or preferring the same medical institution once more and generally favourable thoughts about the services provided

\begin{tabular}{|c|c|c|}
\hline Recommendation* & $\begin{array}{l}\text { Preference for* } \\
\text { the second time }\end{array}$ & $\begin{array}{c}\text { Favourable opinions } \\
\text { about the service } \\
\text { provided }\end{array}$ \\
\hline
\end{tabular}

Comfortable waiting area

in the registration, and admission office

0.413

0.511

$0.187 * *$

Shorter waiting period for analyses/

examinations

0.349

0.310

$0.455^{*}$

General cleanliness of outpatient clinics

0.391

0.300

$0.387 * *$

Physician's sparing some time for

informing patients

0.299

0.243

0.358

Communication between the patient and

the examining physician

0.399

0.198

0.328

Communication of the health care personnel

0.468

0.628

0.637

Respecting privacy of the patients

0.406

0.468

0.343

r: correlation coefficient; $*$ : $p<0.0001 ; * *$ : $<0.01$.

sion analysis, shorter waiting period for analytical procedures ( $p=0.000 \mathrm{CI}: 0.084-0.16$ ), and comfortable waiting area in the registration and admission office ( $p=0,02$ CI: 0.0009-0.11) were the independent variables. Table 3 shows the regression analysis.

In conclusion, patients' evaluation of outpatient health care services "as favourable" has been directly associated with waiting period before the procedures of registration and analysis. The primary factor influencing patients'preference for a certain institution for the second time, or its advisability has been related to communication skills of the health care personnel. Favourable evaluation of health care services, their preference for the second time or their advisability are interrelated factors. If the services of an individual institution are usually approved by the patients, then it is more frequently preferred, and recommended $(p<0.05)$.

\section{DISCUSSION}

Patient satisfaction constitutes an important component of the quality of health care services. Since health care services can not be 'reserved for future use' and they are influenced by many factors, it is hard to measure the quality of service. The presence of many influential factors such as conditions related to patients, medical staff, and institution complicate measurement of the quality of the service [6]. Determination of the patients' satisfaction level is a must for providing services of higher quality, orientation, and management of health care systems [7]. In recent years, interest in patient satisfaction both in private, and public health care institutions is gaining momentum, and studies on measurement tools of patient satisfaction are becoming more prevalent [1]. Although an exact cut-off value for patient satisfaction used in relevant studies is not available, satisfaction rates over $70 \%$ have been asserted to reflect favourable satisfaction levels [8]. In our study, a $96.31 \%$ patient satisfaction rate was detected for the previous six months. Therefore, we can say that our patients are very much satisfied with health care services of this hospital. These higher levels of patient satisfaction might be at least partially attributed to the fact that Gölcük Necati Çelik State Hospital is the only hospital in our region without any competing health care institution.

Various factors affect patient satisfaction. These have indicated as factors related to patients, health 
TABLE 3. Regression analysis results of the factors related to preferring, and recommending a certain health care institute, and generally favourable thoughts about the services provided

$p$ value

CI (95\% confidence interval)

Reasons for preferring the same institute

Communication skills of the examining physician

0.001

$-0,33-0.08$

Communication skills of the other health care personnel

0.000

$0.24-0.47$

Comfortable waiting area in the registration, and admission office

0.280

$0.2-0.64$

Shorter waiting period for analyses/examinations

0.380

$0.86-1.67$

General cleanliness of the outpatient clinics

0.268

$0.93-1.89$

Physician's sparing some time for informing patients

0.567

$0.96-2.5$

Respecting privacy of the patients

0.124

$0.23-0.46$

Reasons for recommending a health care institution

Communication skills of the examining physician

0.000

0.14-0.43

Communication skills of the other health care personnel

0.037

$-0.32-0.01$

Comfortable waiting area in the registration, and admission office

0.290

$-0.44-1.5$

Shorter waiting period for analyses/examinations

0.512

$1.5-3.8$

General cleanliness of the outpatient clinics

0.122

$0.3-4.2$

Physician's sparing some time for informing patients

0.321

$0.8-2.2$

Respecting privacy of the patients

0.486

$0.21-0.41$

Favourable acceptance of the health care services provided

Comfortable waitinm area in the registration, and admission office

0.02

$0.0009-0.11$

Shorter waiting period for analyses/examinations

0.000

$0,084-0,16$

General cleanliness of the outpatient clinics

0.188

$-1.2-2.5$

Physician's sparing some time for informing patients

0.798

2.6-6.4

Communication skills of the examining physician

0.865

$2.5-4.8$

Communication skills of the other health care personnel

0.122

$1.2-3.4$

Respecting patients' privacy

0.129

$1.9-6.7$

care providers, and institutions $[3,4,5]$. Patientrelated factors cited in the literature demonstrate variations [3, 8-13]. Konca et al., Çelikkalp et al. did not detect any significant correlation between sociodemographic factors and satisfaction levels [9, 10]. In other relevant studies Hekkert et al,, Quintana et al., Ercan et al. revealed the presence of a correlation between sociodemographic factors and satisfaction scale scores [11-13]. However, in our study, a significant correlation was not detected between the satisfaction rates of the ambulatory patients and personal characteristics of the patients ( $p>0.05)$. We think that the reason for arriving at different conclusions as cited in the literature is related to the diverse sociocultural characteristics of the study sites.
Previous studies acknowledged that a patient satisfied with the health care services both prefer and advise the same service $[9,13,14]$. The prevalence rates of patients' preference for the same institution they were satisfied with varied in the Turkish medical literature. Önsüz et al. 76.7\%, Aytar, and Yeşildal et al. 93.4\%, and Konca et al. 99\% [3, 9, $15]$. In our study, $93.3 \%$ of our patients preferred the same institution for the second time. In the literature, communication skills of medical personnel have been reported as the most important factor influencing patient satisfaction $[4,16-18]$. Communication induces establishment of confidence among individuals $[19,20]$.

Professional approach of the medical staff, their affection, and interest to patients increase patient's 
compliance to treatment and participation in medical decisions [21]. Attitudes and behaviors of the personnel, rather than a technical, and clinical characteristics of the hospital have been indicated as important factors in patients' repetitive preferences of the same hospital [22]. Also in our study, attitudes, and behaviours of the physicians, and health care personnel were found to be the most important factors for the preference of the same institution. Previous studies were done by Tükel et al. and Önsüz et al. in different settings. They found that most of the patients were recommending their health care service to others ( 88.6 and $70.7 \%$, respectively) [3, $7]$. In our research, the rate of advisability was much higher (92.9\%). Another study performed in Izmir, physical conditions of the hospital were found to be the least important service quality dimension [23]. As a consequence, recommending or preferring an individual institution for the second time is related to the communication skills of the health care staff. These outcomes indicate the importance of medical personnel in providing improved quality of healthcare systems. When we analyzed perceptions, and expectations of the patients, health care service quality, preference, and the advisability were found to be intermingled, and integrated factors. Professional approach and attitudes of the healthcare providers and their ways of transferring their knowledge and skills to those needed, play a significant role in patient satisfaction. When we evaluated components of the service, shorter waiting period ensures more proper evaluation of the service offered while preference and the advisability of the institute are also related to communication skills of the medical staff.

Limitation of this study is its cross-sectional design, and so its outcomes can not be generalized. Since patient satisfaction questionnaire of the study performed has a higher internal consistency, and reliability, we can be sure of reliability of the present study. Apart from other satisfaction surveys, the present study analyzed the components of the health care services and detected deficiencies and patients' expectancies. In this respect, we think that the present study will shed light on future studies on patients' satisfaction.

Studies concerning patient satisfaction provide feedback for offering a high-quality health care and determination of institutional targets. According to the results of the present study, we think that increasing communication skills and decreasing the number of the patients on the waiting list will increase patients' satisfaction with health care services. The present study has revealed that patient satisfaction surveys should not be evaluated only by the satisfaction scores, but at the same time it should be analyzed based on the components of the service offered. In our study, the only element which is useful on advisability, and preference of an institute was found to be the professional attitudes and communication skills of health care personnel independent from other factors. In conclusion, we think that reinforcing communication skills of the medical staff with in-service training provided by the institutions, and satisfaction of the medical professionals for efficient working are essential.

Conflict of Interest: No conflict of interest was declared by the authors.

Financial Disclosure: The authors declared that this study has received no financial support.

\section{REFERENCES}

1. Aslantekin F. Sağlık hizmetlerinde kalite deneyimi: Dr. Ekrem Hayri Üstündağ Kadın Hastalıkları ve Doğum Hastanesi Örneği. Fırat Sağlık Hizmetleri Dergisi 2007;2:55-71.

2. Kanber NA, Gürlek Ö, Çiçek H, Gözlükaya A. Bir Sağlık Kurumunda Sağlık Çalışanlarının Memnuniyeti. Sağlıkta Performans ve Kalite Dergisi 2010;2:114-27.

3. Önsüz M, Toğuzoğlu A, Cöbek U, Ertürk S, Yılmaz F, Birol S. İstanbul'da Bir Tip Fakültesi Hastanesinde Yatan Hastaların Memnuniyet Düzeyi. Marmara Medical Journal 2008;21:33-49.

4. Yılmaz M. Sağlık bakım kalitesinin bir ölçütü: hasta memnuniyeti C. Ü. Hemşirelik Yüksekokulu Dergisi 2001;5:69-74.

5. Özer A, Çakıl E. Sağlık hizmetlerinde hasta memnuniyetini etkileyen faktörler. Tip Araştırmaları Dergisi 2007:5:140-3.

6. Pala T, Saatlı G, Eser E. Hastanede yatan hastaların hastane hizmetleri ve hastane çalışanlarından memnuniyeti ve bunu oluşturan bileșenler. 8. Ulusal Halk Sağlığ1 Kongresi Bildiriler Kitab1, Diyarbakır; 2003:538-41.

7. Tükel B, Acuner A, Önder Ö, Üzgül A. Ankara Üniversitesi İbn-i Sina Hastanesínde yatan hasta memnuniyeti (genel cerrahi anabilim dalı örneği). Ankara Üniversitesi Tıp Fakültesi Mecmuas1 2004;57:205-14.

8. Şahin T, Bakıcı H, Bilban S, Dinçer Ş, Yurtçu M, Günel E. 
Meram Tip Fakültesi Çocuk Cerrahisi Servisinde yatan hasta yakınlarının memnuniyetinin araștırılması. Genel Tip Dergisi 2005;15:137-42.

9. Konca G, İlhan NM, Bunin MA. "Yatarak Tedavi Gören Hastaların Hastane Çalıșanları ve Hastane Hizmetlerinden Beklentileri ve Beklentilerine ilişkin Memnuniyet Durumlarının Değerlendirilmesi". Gazi Tıp Dergisi 2006;17:160-70.

10. Çelikkalp Ü, Temel M, Saraçoğlu G, Demir M. Bir Üniversite Hastanesinde Yatan Hastaların Hizmet Memnuniyeti. Firat Sağlik Hizmetleri Dergisi 2011;6:1-14.

11. Hekkert KD, Cihangir S, Kleefstra SM, van den Berg B, Kool RB. Patient satisfaction revisited: a multilevel approach. Soc Sci Med 2009;69:68-75. CrossRef

12. Quintana JM, González N, Bilbao A, Aizpuru F, Escobar A, Esteban C, et al. Predictors of patient satisfaction with hospital health care. BMC Health Serv Res 2006;6:102. CrossRef

13. Ercan İ, Ediz B, Kan İ. "Sağlık Kurumlarında Teknik Olmayan Boyut için Hizmet Memnuniyetini Ölçebilmek Amacıyla Geliştirilen Ölçek". Uludag Üniversitesi Tip Fakültesi Dergisi 2004;30:151-7.

14. Argan M, Argan TM. "Bursa İlindeki Özel Hastanelerde Poliklinik Hizmeti Alan Hastaların Kalite Algılamaları ve Memnuniyeti Üzerine Bir Araştırma", Modern Hastane Yönetimi Dergisi 2004;3:46-57.

15. Aytar G, Yeşildal N. Yatan Hasta Memnuniyeti. Düzce Tip
Fakültesi Dergisi 2004;3:10-4.

16. Avis M, Bond M, Arthur A. Satisfying solutions? A review of some unresolved issues in the measurement of patient satisfaction. J Adv Nurs 1995;22:316-22. CrossRef

17. Avis M, Bond M, Arthur A. Exploring patient satisfaction with out-patient services. J Nurs Manag 1995;3:59-65. CrossRef

18. Meredith P. Patient satisfaction with communication in general surgery: problems of measurement and improvement. Soc Sci Med 1993;37:591-602. CrossRef

19. Williams OA. Patient knowledge of operative care. J R Soc Med 1993;86:328-31.

20. Uz HM, Özbakır D, Ergin C. Birinci basamak sağlık hizmetlerinde hasta memnuniyeti: bir saha çalışması, Sağlık Hizmetlerinde Toplam Kalite Yönetimi ve Performans Ölçümü, Ankara Haberal Eğitim Vakfı 1997;113-8.

21. Alcan Z. Bayınndır Tip Merkezi hemşirelik hizmetleri müdürlüğü hasta memnuniyet anket sonuçları. Çoruh $\mathrm{M}$ (ed). Sağlık hizmetlerinde toplam kalite yönetimi ve performans ölçümü, Ankara Haberal Eğitim Vakfi 1997;133-8.

22. Kavuncubaşı Ş. Hastane ve sağlık kurumları yönetimi. Siyasal kitabevi. Ankara 2000;291-304.

23. Devebakan N, Yağcı K. Sağlik işletmelerinin algılanan hizmet kalitesi düzeylerinin karşılaştırmasında SERVQUAL yöntemi. Sağlik ve hastane yönetimi 2. Ulusal Kongresi bildiriler kitabı Ankara 2005;543-53. 